\title{
EQUILIBRIUM
}

Quarterly Journal of Economics and Economic Policy

2016 VOLUME 11 ISSUE 1, March

p-ISSN 1689-765X, e-ISSN 2353-3293

www.economic-policy.pl

Heryán, T., \& Ziegelbauer, J. (2016). Volatility of Yields of Government Bonds Among GIIPS Countries During the Sovereign Debt Crisis in the Euro Area. Equilibrium. Quarterly Journal of Economics and Economic Policy, 11(1), pp. 61-74, DOI: http://dx.doi.org/10.12775/ EQUIL.2016.003

Tomáš Heryán, Jan Ziegelbauer*

Silesian University in Opava, Czech Republic

\section{Volatility of Yields of Government Bonds Among GIIPS Countries During the Sovereign Debt Crisis in the Euro Area**}

JEL classification: $C 58$; $G 01 ; G 15$

Keywords: yield of government bonds; volatility; GIIPS countries; GARCH and TARCH models

\begin{abstract}
The aim of the paper is to estimate, how the volatility of yields of the Greek bonds affects yields' volatilities of bonds in selected European countries during the period of the sovereign debt crisis in the euro area. We obtained data for 10-year bonds in a weekly frequency from January 2006 till the end of December 2014. To make a comparison of pre-crisis period, we firstly investigate a bond yields' volatility before 15th September 2008, when U.S. Leman Brothers bankrupted and the global financial crisis had been reflected in full. However, the period of the global financial crisis could also negatively affect the development of government bonds. Therefore, the period after Leman Brothers' bankruptcy has been excluded and our crisis period starts after 23rd April 2010, when Greece asked the IMF for financial help and the sovereign debt crisis had been reflected in full. Volatility models GARCH $(1,1), \operatorname{IGARCH}(1,1)$ and TARCH $(1,1)$ were used as an estimation method. To examine the risk premium of all GIIPS
\end{abstract}

(C) Copyright Institute of Economic Research

Date of submission: June 17, 2015; date of acceptance: December 12, 2015

* Contact: heryan@opf.slu.cz, Silesian University in Opava, School of Business Administration in Karviná, Univerzitní nám. 1934/3,733 40 Karviná, Czech Republic

** This paper was supported by the Ministry of Education, Youth and Sports Czech Republic within the Institutional Support for Long-term Development of a Research Organization in 2015 . 
economies (Greece, Ireland, Italy, Portugal and Spain), we also compared the whole investigation with the developments of each spread against the yields of German government bonds. Our results clearly proved not only big differences between pre-crisis and crisis period, but also differences in output with the bond yield spreads. It was concluded that there has been a higher impact of the Greek bond yields, as well as yield spreads volatility in 2010 and 2011, while it is on the lower level in pre-crisis period.

\section{Introduction}

Government debt and its financing is a highly frequented issue among researchers from the whole world. The sovereign debt crisis, which escalated in the Economic and Monetary Union (EMU) in 2010, has sparked big debates about its causes and possible solutions, both in academic and political institutions (Costantini et al., 2014). However, the situation in the EMU which started the sovereign debt crisis should still be paid attention to, due to its negative impacts on other European economies. The term structure of government bond yields is a key source of information regarding investors' views on inflation and economic growth (Ejsing et al., 2015). Volatility is one of the most important determinants of asset value for stocks as well as bonds, the two most important asset classes (Zhou, 2014). Financial integration has increased the interdependence between asset markets, and in particular sovereign bond markets. The European debt crisis shows that fiscal trouble can transmit unexpectedly fast even between sovereign bond markets (Claeys \& Vašíček, 2014).

The main objective of the current study is to estimate how a volatility of yields of the Greek bonds affects yields' volatilities of bonds in selected European countries during the period of the sovereign debt crisis in the euro area. Our estimated period is from January 2006 till December 2014. To make a comparison it is divided into two sub-periods due to the sovereign debt crisis in the EMU, the crisis and pre-crisis. Many studies investigate the issue of government bonds and the crisis. The contribution of the paper is that we prove particular impacts of the Greek bonds development on another GIIPS countries (Ireland, Italy, Portugal and Spain), also in view of differences due to increasing market risk during the crisis.

The paper is structured as follows: the next section describes the current state of knowledge in selected issue and contains two matters to differ between economic events from the estimated period, as well as includes the revision of related literature. Then there is the section which describes the used data and methodology of GARCH, IGARCH and TARCH models. 
After that, there is a discussion on our empirical results in the next section. Finally, the last section concludes.

\section{The Current State of Knowledge}

In this section, the problems related to the sovereign debt crisis in the EMU are briefly described, and later on literature sources related to the issue are reviewed. The World Bank defines sovereign debt as the entire stock of direct government fixed-term contractual obligations to others outstanding on a particular date. It includes domestic and foreign liabilities, such as currency and money deposits, securities other than shares, and loans. It is the gross amount of government liabilities reduced by the amount of equity and financial derivatives held by the government. As the debt is a stock rather than a flow, it is measured for a given date, usually the last day of the fiscal year.

The date which can be considered a milestone of the European debt crisis is April 2010, when the European Union authorized three-year assistance amounting 110 billion EUR for Greece. Hruška (2010) provides several reasons why the situation in Greece was so desperate. The worst role was played by their "creative accounting", used in Greece to improve its reputation within the Eurozone. Until 2009 Greece did not confer the extent of its debt with the help of American banks, which plastered the Greek budget hole using a non-existent appreciation of the Greek debt on derivative markets. Another trick consisted of counting debt from unpaid social security contributions in belief that it should be eventually collected. One of the most important reasons of the disastrous situation in Greece was the extensive black economy. Estimates of Greek economists spoke in 2010 about 30 billion EUR of tax evasion and other nine billion EUR as a loss of the state health insurance company IKA.

The opinion across Europe in March 2011 was that Greece should leave the EMU and return to their drachma currency. Němec (2011a) states the opinion of economists that a return to their own currency would help the country regain its lost competitiveness and restore an economic growth as well. However, leaving the Eurozone was all the time utopian. The EU has not had the legislation for this act. The forecasts for the Greek economy were even more skeptical in September 2011. Němec (2011b) reported that the probability of insolvency was $98 \%$. The Greek debt grew despite tax increasing and savings and the economy was in recession. The Bankruptcy seemed inevitable. Therefore, the second bailout loan of 130 billion EUR for Greece was approved in February 2012. Following this event, agency 
Moody's reduced rating of Greece to level C, the lowest possible rating. Massive demonstrations against the government authority were held in Greece during 2012 and 2013. The Greek recession ended in the third quarter of 2014, after six years.

The second country which requested assistance in November 2010 was Ireland. Although the country was considered as a showcase for the EU as well as for the EMU due to its successful and growing economy, the Irish economy suffered from the collapse of banks at the beginning of the global financial crisis. The government invested significant amounts of EUR into the banking sector. The major problem that started the crisis in Ireland was the burst of real estate bubble in 2008, which caused a significant decline in property prices and left the Irish banks with high loans.

Italy was after the Greece in the worst situation due to their public debt but never asked for a bailout. Němec (2012) reported that the total debt of Italy was 1.9 trillion EUR (120\% of GDP), and estimated that the necessary help for Italy should be a half of trillion EUR in 2012, according to him. Moreover, Italy was the major investor in the Greek government bonds before the crisis.

In March 2011 Portugal became one of the risky economies, too. Břeštan (2011) argues that Portugal was in an unflattering position after the government had not supported the austerity package of Prime Minister Jose Socrates. Following this event, the ratings of Fitch agency for the country decreased to rating (A-). At that time, however, Portugal still refused the financial help from abroad. This fact proves the Portugal case is different than the one of Greece or Ireland.

Spain requested financial assistance in June 2011. The causes of the crisis were very similar to Ireland. The local economy flourished until 2008. The Spanish standard of living was approaching the rest of the Western Europe. Their construction boom was magnificent. Nevertheless, the bursting of the mortgage bubble in the United States affected the overheated economy of Spain (Dolejš, 2010).

Figure 1 illustrates the development of government debt in all GIIPS countries and its share on GDP. We see that even if Greece used their creative accounting, the share is more than $100 \%$ in whole period from 2002 to 2012. A similar situation is in Italy. We see that the share increased very sharply in 2011 in all economies. Ireland and Portugal crossed the border of $100 \%$ in 2012, as well. The lowest share of the debt on GDP is in Spain. Nonetheless, in all GIIPS countries we see an increase in 2008 due to the global financial crisis, which could be a significant problem that caused the sovereign debt crisis in the EMU, in our opinion. However, the problem is more complicated. 
Figure 1. Central government debt in GIIPS countries (\% of GDP)

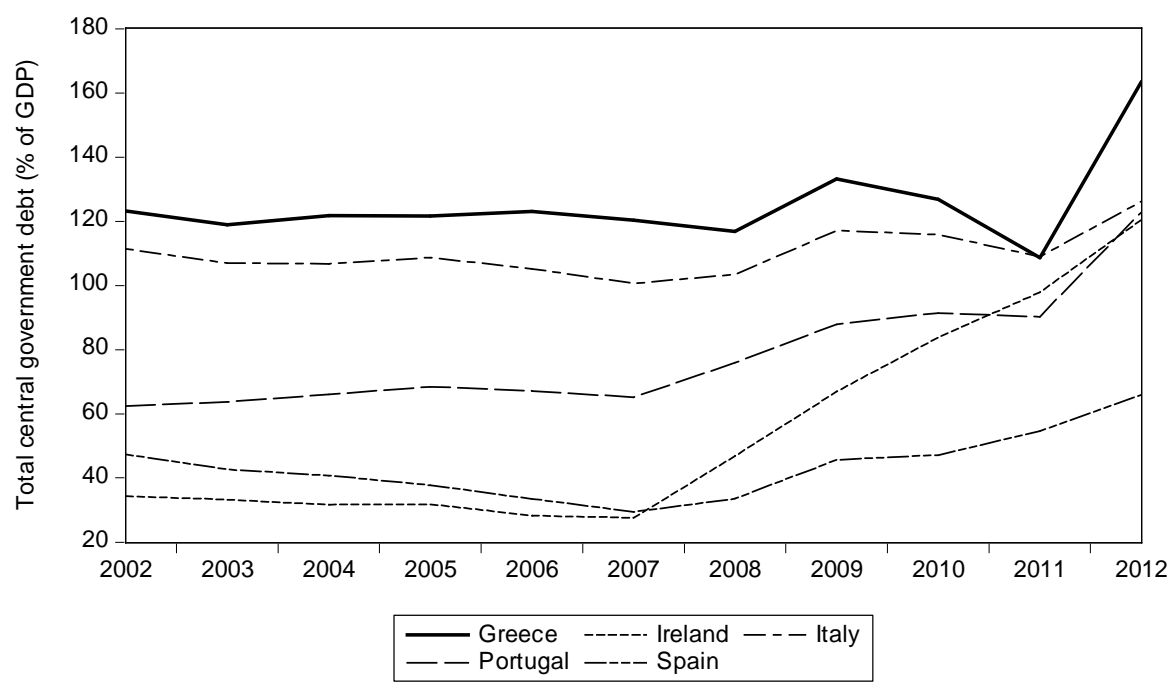

Source: Authors' illustration from the World Bank statistical database.

Guarín et al. (2014) investigated the relationship between the US and Colombian sovereign debt interest rates between 2004 and 2013. The analysis is performed on three sample periods (i.e. before, during, and after the global financial crisis). Their findings show that the link between sovereign bond yields has changed over time. Moreover, the short-run responses of local asset prices to foreign financial shocks have been qualitatively different in the three periods. They employ a VARX-MGARCH model to compute the short-term response of local asset prices to foreign financial shocks.

Costantini et al. (2014) argued, since the start of the EMU and before its sovereign debt crisis, that the spreads on 10-year sovereign bond yields relative to the German benchmark were small. With the crisis, the picture completely changed. In particular, they argue that the statistical significance attached to cumulated inflation differentials is an indication that the economies included in the sample of countries do not belong to an optimal currency area. In fact, if shocks were sufficiently correlated or if the monetary union was able to absorb and balance out asymmetric shocks, then cumulated inflation differentials would be small and unimportant for sovereign bond yield spread determination.

Sovereign bond yield spread spillovers between the Euro zone countries during a turbulent period encompassing both the global financial crisis and the EMU sovereign debt crisis is investigated in Antonakakis and Vergos 
(2013). Their findings highlight the increased vulnerability of the EMU from the destabilizing shocks originating mostly from the Euro zone countries in the periphery (Greece, Ireland, Italy, Portugal and Spain (GIIPS)), and to a lesser extent from the Euro zone core. The findings are partly in contrast with findings of early studies that showed yield convergence among European countries before the financial crisis. They highlight a few of events since the mid of 2008 as: (i) the collapse of Lehman Brothers in September 2008; (ii) the European stimulus plan proposed by the European Commission on November 2008, (iii) November 2009, when the Greek government revised its public sector deficit to $12.7 \%$ of GDP from the $6 \%$ originally stated; (iv) Greece's application for bailout on April 2010 from the EU and the International Monetary Fund (IMF) and (v) acceptance on May 2010 that other countries would follow the same course of action which ultimately could lead to the breakdown of the EMU.

Ejsing et al. (2015) disentangled credit and liquidity premia in highly rated and very liquid sovereign markets for the last 15 years, including the financial crisis of 2008-2009 and the sovereign debt crisis of 2010-2012 in a state-space framework. Their study quantifies liquidity and credit premia in German and French government bond yields. For this purpose, we estimated the term structures of government-guaranteed agency bonds and exploited the fact that differences in their yields vis-à-vis government bonds are mainly driven by liquidity effects in these two developed EU countries.

Claeys and Vašíček (2014) analyze the bilateral linkages between EU sovereign bond markets over time using forecast-error variance decompositions from VAR model with daily data since 2000 on the sovereign bond yield spreads of the EU countries. They argue that the use of the yield spread over the reference yield, which is usually taken to be the risk-free rate, is common in the literature. The idea is to analyze only the part of the domestic yield that is not driven by changes in the risk-free rate. However, this approach has a caveat, as it does not allow them to assess the spillover to and from the reference country. This may be particularly relevant if the reference country enjoys safe haven status (as Germany arguably does) when investors fly to quality bonds.

The influence of macroeconomic fundamentals and the underlying 10 years Greek government bonds is investigated in Chionis et al. (2014). They examine the period between Q1:2001 up to the end to Q4:2012, applying four major macroeconomic variables such as the debt to GDP ratio, deficit, inflation and unemployment. They found that deficit, inflation and unemployment among others, play a more significant role as the determinants of the 10-year Greek bond yield, while isolating the period during the 
crisis macroeconomic factors strengthens their effect on the Greek debt market. Undoubtedly, it is remarkable finding that during the crisis the change in the growth rate does not appear to be among the factors leering investors. The current account balance was among the top determinants of the Greek bond yields only for the period during the crisis. They conclude that during the time before the memorandum, both inflation and unemployment seem to be significant determinants for the yield. Immediately after the burst of the Greek crisis, in addition to the abovementioned factors, a new factor seems to be significant, which is the fiscal deficit while the growth rate does not have any significant impact on the yield.

Due to the studies selected, we will use volatility models and we should split our estimated period into some sub-periods, as well. It is obvious that it is impossible to investigate whole period due to the global financial crisis as well as due to sovereign debt crisis.

\section{Method of the Research}

We obtained a data in weekly frequency from online statistical database investing.com. The estimated period is from January 2006 till December 2014. We obtained yields for 10 years government bonds in Greece, Ireland, Italy, Portugal and Spain (GIIPS countries), and also make its spreads against the yields of 10 years bonds in Germany to examine risk of selected countries (see Claeys \& Vašíček, 2014; Ejsing et al., 2015). We split our whole estimated period into two sub-periods, pre-crises period from January 2006 to $15^{\text {th }}$ September 2008 when global financial crisis had been reflected in full, and the crisis sub-period from $23^{\text {rd }}$ April 2010 to December 2014 (see Antonakakis \& Vergos, 2013). We excluded the times affected with the global financial crisis to estimate relations in the sovereign debt crisis because we investigated the relations among selected European bond markets.

We employ two estimation methods GARCH $(1,1)$ and TARCH $(1,1)$ models to show the differences within the Greek bonds volatility (among yields as well as among spreads), and its impact on the development in remaining GIIPS countries. As the first estimation method, we employ the GARCH $(1,1)$ model which is described in according Asteriou and Hall (2011) by equation (1) and (2): 


$$
\begin{aligned}
& Y_{t}=\alpha_{0}+\alpha_{1} Y_{(t-1)}+\alpha_{2} G R_{t}+\alpha_{3} A R(1)+\varepsilon_{i}, \\
& h_{t}=\gamma_{0}+\beta_{1} h_{(t-1)}+\gamma_{1} \varepsilon_{(t-1)}^{2},
\end{aligned}
$$

where $Y_{i t}$ means firstly the volatility of bond yields or secondly volatility of spread against German yields in GIIPS countries (Italy, Ireland, Portugal, Spain) in time $t$. All selected countries are investigated separately to show the differences between each country as well as between both estimated sub-periods. The variable $Y_{(t-1)}$ means GARCH, $G R_{t}$ is always the volatility of Greek bond yields or the volatility of the spread against the German yields again. Symbols $\alpha_{i}$ and $\varepsilon_{i}$ are constant and residuals of each equation. Sometimes auto-regression $A R(1)$ is included just in cases damaged by the level of autocorrelation among residuals. In variance equation $h_{i t} \alpha_{0}$ is included as a constant, one lagged value of GARCH $h_{(t-1)}$, and $\varepsilon_{(t-1)}^{2}$ as one lagged value of squared residuals. For further description of the methodology please see also Drachal $(2015,2016)$.

As the second estimation method, we deploy also TARCH $(1,1)$ model which differs from GARCH $(1,1)$ in variance equation (3):

$$
h_{t}=\gamma_{0}+\beta_{1} h_{(t-1)}+\gamma_{1} \varepsilon_{(t-1)}^{2}+\vartheta_{1} D_{(t-1)} \varepsilon_{(t-1)}^{2},
$$

where $D_{i(t-1)}$ is a dummy variable. Stavárek (2010) argues that the core of the TARCH term is the dummy variable that equals 1 in the case of a negative shock and zero otherwise. Thus, a positive value of the coefficient $\vartheta_{i}$ means that the positive innovations (increase of the yield or spread) tend to increase the subsequent volatility more than the negative shocks do (decrease).

As the third estimation method, we deploy integrated GARCH $(1,1)$ due to fact that the sum of ARCH and GARCH coefficients $\sum\left(\beta_{1}+\gamma_{1}+\vartheta_{1}\right)$ among GARCH $(1,1)$ models, exceeds the value one. Otherwise, if one restricts the parameters of the GARCH model to sum to one and drop the constant term from (2), then we have an IGARCH. 


\section{Discussion on Empirical Results}

In table 1 and 2, we see that the volatility of Greek bond yields as well as the volatility of the spread against German bond yields, are both significant in all cases for all selected GIIPS countries (Italy, Ireland, Portugal and Spain) in the sub-period of the sovereign debt crisis in the EMU.

Engle et al. (2007) noticed that the coefficients sum up to a number slightly less than one. Coefficients of GARCH/TARCH models summing up to more than one (see $\sum\left(\beta_{1}+\gamma_{1}+\vartheta_{1}\right)$ ), is an indication that a stationary GARCH model is unlikely to fit the data well. Whether the GARCH $(1,1)$ coefficients $\sum\left(\beta_{1}+\gamma_{1}+\vartheta_{1}\right)$ summed up to exactly one, using an IGARCH model would be a natural choice. In our case, we really see that almost all of the GARCH $(1,1)$ parameters sum up to more than one. Hence, IGARCH is not that natural (although more plausible than a stationary GARCH). On the other hand, we also see that in almost all the cases of TARCH $(1,1)$ parameters sum up to less than one. Therefore, we really see the results in good condition among TARCH models. Stavárek (2010) argues that the sum of the ARCH and GARCH term coefficients tells us about the convergence of variables to a steady state. If the sum is below one, there is evidence of convergence. The closer the sum is to one, the slower the convergence that can be observed. In Table 3, we see that all variables are statistically significant while we run IGARCH $(1,1)$ models. The assumption of IGARCH model is that the sum of variance equation's coefficients is exactly the value one. Therefore, we can argue that all our estimations of TARCH $(1,1)$ models are all in good condition (except the result for the cases of bond yields in Italy and the spread in Ireland, which still suffer with heteroscedasticity ARCH).

Interesting finding is, even although Italy was the major investor to the Greek bonds, the highest impact is estimated in the case of Portugal. However, the case of Italy suffers from ARCH and there is insignificant coefficient $\vartheta_{1}$ of dummy variable within the yields of Ireland. In all four countries, a negative coefficient $\vartheta_{1}$ of dummy variable within TARCH models is estimated. It is a bit surprising for us because it means that a negative change of the Greek bond yields affects the volatility of other GIIPS bond yields more than a positive change, which means an increase of risk (except Italy and Ireland). We argue that it is caused by behavioral aspects of investors who tried to sell the GIIPS bonds for its higher price in particular moments during the crisis period. If the yields of the bonds decreased, the price of the bonds should increase simultaneously. So, this fact is connected with psychological analysis and herd behaviour of investors. Our results support Galariotis et al. (2015), who provides the first original evidence on 


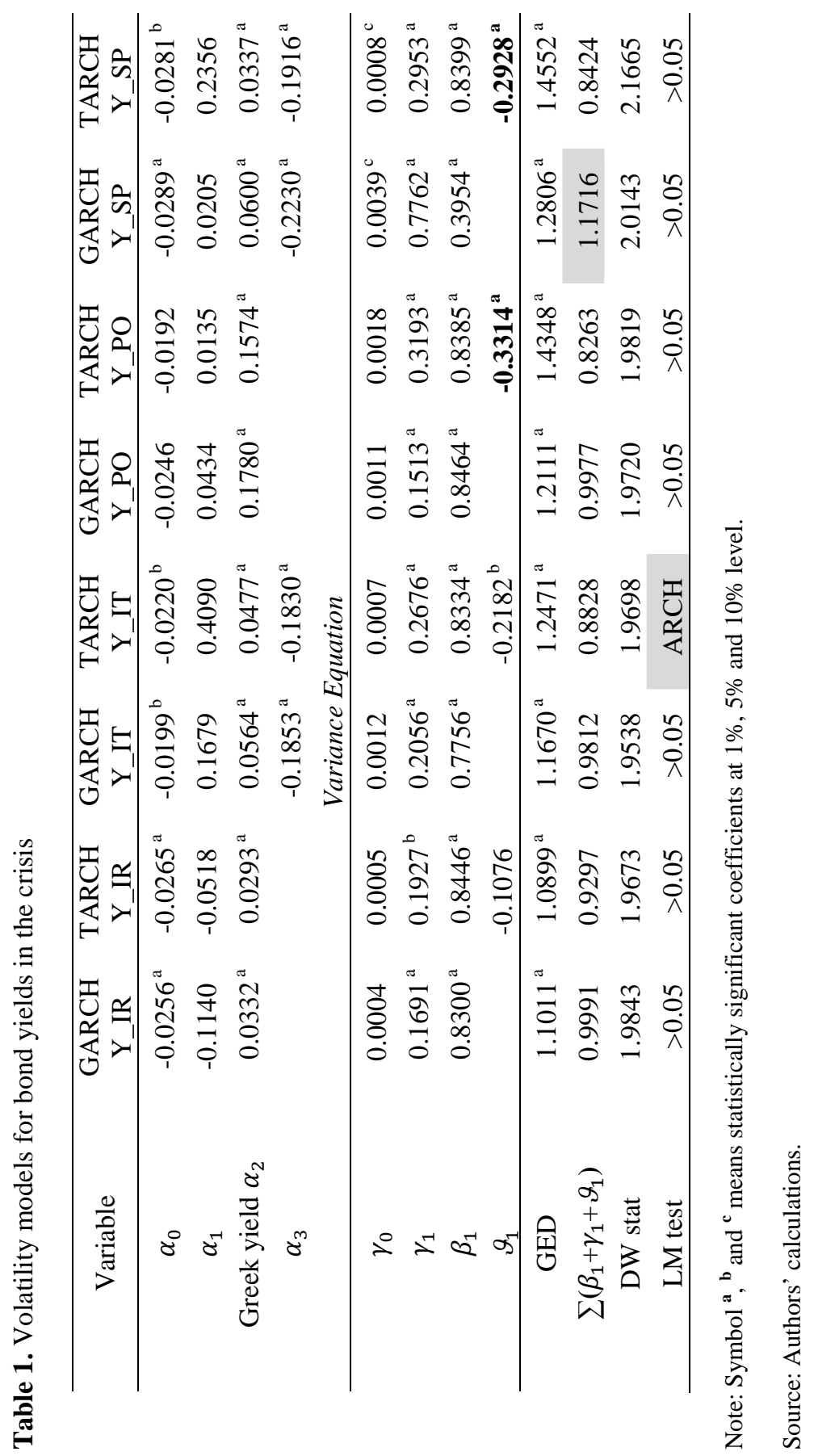




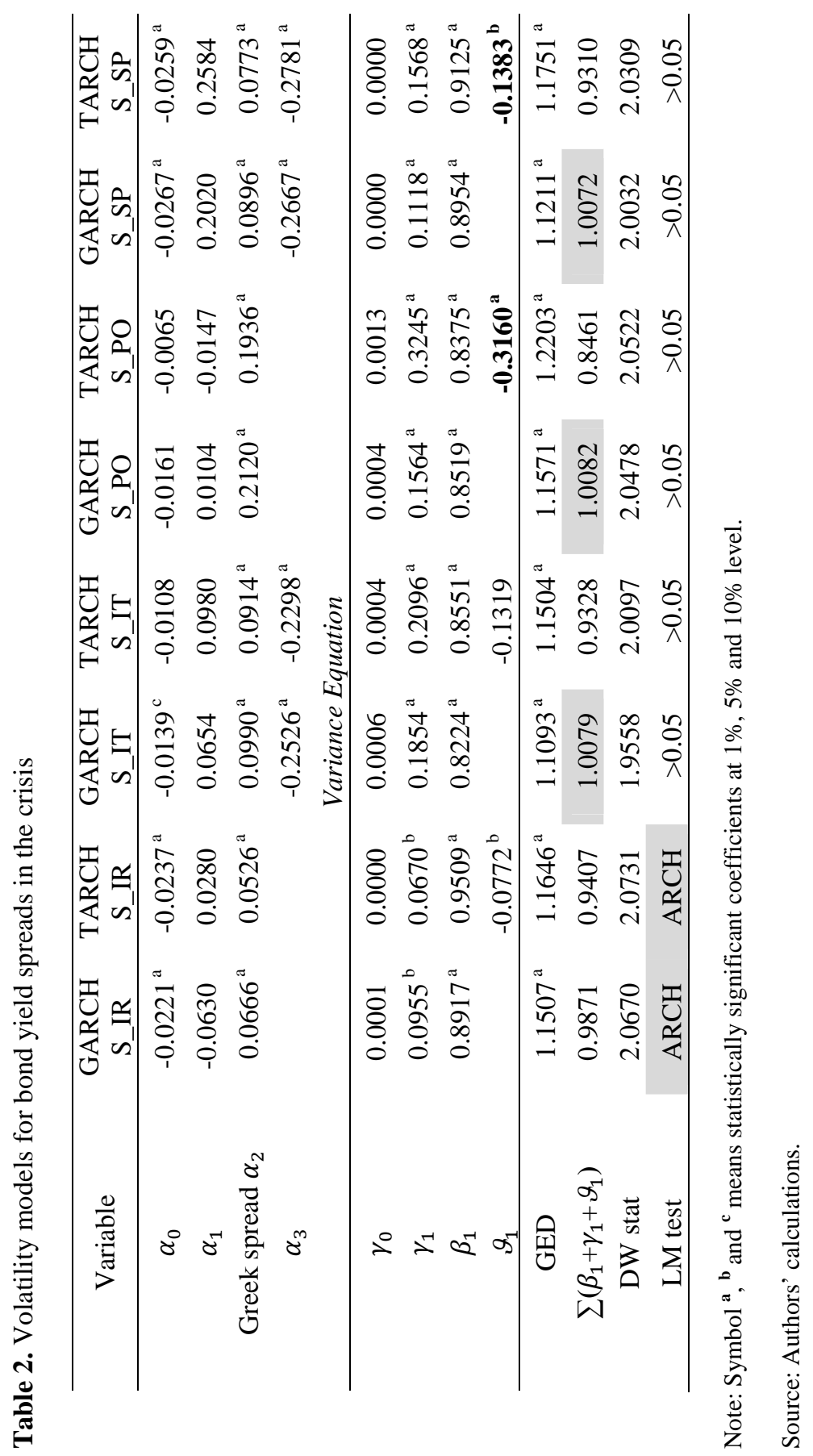


herd behavior in European government bond prices during the EU crisis. They find that during the crisis period macroeconomic information induces bond market investor herding.

The second case of the GIIPS bond yields spreads against the yields of 10 years bonds in Germany, to examine the risk of selected countries, is illustrated in Table 2. We see that the volatility of the Greek bond spread impacts again on volatilities of other GIIPS bond spreads as it was in the case with volatility of the bond yields. Nonetheless, here the risk premium over the less risky government bonds of developed country with lower yields, Germany, is investigated. However, we see a negative sign of dummy variable coefficient $\vartheta_{1}$ within TARCH models again. Whenever the Greek bond spread increased, the bond spreads in Portugal and Spain increased simultaneously. It is the most surprising, because it means a negative relation between the Greek market risk and market risk of two GIIPS countries. During the pre-crisis period, not only all TARCH dummy variable coefficients $\vartheta_{1}$ are insignificant, but even not all variance equations are significant. Therefore, we cannot see these relations among the volatilities before the sovereign debt crisis in the EMU.

Table 3. IGARCH $(1,1)$ models instead the GARCH $(1,1)$

\begin{tabular}{ccccc}
\hline & Y_SP & S_IT & S_PO & S_SP \\
\hline$\alpha_{0}$ & $-0.0333^{\mathrm{a}}$ & $-0.0151^{\mathrm{b}}$ & $-0.0163^{\mathrm{a}}$ & $-0.0268^{\mathrm{a}}$ \\
$\alpha_{1}$ & 0.1941 & 0.1019 & 0.0164 & 0.2128 \\
Greek variable $\alpha_{2}$ & $0.0588^{\mathrm{a}}$ & $0.0969^{\mathrm{a}}$ & $0.2099^{\mathrm{a}}$ & $0.0882^{\mathrm{a}}$ \\
$\alpha_{3}$ & $-0.1759^{\mathrm{a}}$ & $-0.2427^{\mathrm{a}}$ & & $-0.2687^{\mathrm{a}}$ \\
& Variance Equation $^{\mathrm{a}}$ & & \\
\hline$\gamma_{1}$ & $0.0882^{\mathrm{a}}$ & $0.1164^{\mathrm{a}}$ & $0.1294^{\mathrm{a}}$ & $0.0998^{\mathrm{a}}$ \\
$\beta_{1}$ & $0.9118^{\mathrm{a}}$ & $0.8836^{\mathrm{a}}$ & $0.8706^{\mathrm{a}}$ & $0.9002^{\mathrm{a}}$ \\
\hline GED & $1.1613^{\mathrm{a}}$ & $1.1468^{\mathrm{a}}$ & $1.1762^{\mathrm{a}}$ & $1.1432^{\mathrm{a}}$ \\
DW stat & 2.1075 & 1.9742 & 2.0475 & 2.0026 \\
LM test & $>0.05$ & $>0.05$ & $>0.05$ & $>0.05$ \\
\hline
\end{tabular}

Note: Symbol ${ }^{\mathbf{a}},{ }^{\mathbf{b}}$ and ${ }^{\mathbf{c}}$ means statistically significant coefficients at $1 \%, 5 \%$ and $10 \%$ level. Source: Authors' calculations.

Table 3 shows us the output for selected IGARCH $(1,1)$ models. We create it just for four GARCH $(1,1)$ models from Tables 1 and 2 with the 
sum of coefficients $\sum\left(\beta_{1}+\gamma_{1}+\vartheta_{1}\right)$ larger than the value 1.00. Because of significant coefficients of integrated IGARCH $(1,1)$ models we see that even the results of those four GARCH $(1,1)$ models are in a good condition.

\section{Conclusions}

The aim of current study was to estimate how a volatility of yields of the Greek bonds affects yields' volatilities of bonds in selected European countries during the period of the sovereign debt crisis in the euro area. To differentiate between two economic values, the development of government bond yields and the value of risk for investors, as well as the spreads against the yields in Germany were examined.

Our results clearly prove that between the development of Greek bonds yields and the yields development in other GIIPS countries (Ireland, Italy, Portugal and Spain), there is an inverse relationship. In the case of the development of the yields spreads the relations are also negative. It means that whenever the Greek bonds yields increased in the crisis period the volatility of other selected yields decreased, and the other way round. Moreover, if the spread in Greece increased, the volatility of other spreads decreased conversely, as well. Our findings are the strongest in the case of Portugal and Spain. In our opinion, it could be caused by some psychological aspects of the investor's behaviour. It is very important that before the sovereign debt crisis in the EMU, these relations have not been estimated.

In the future research, the attention has to be paid to the relations between the price of bonds and its yields, or if the proved effects are stronger when the risk of the countries increased or decreased. It would also be very interesting to compare that problems with the same methodology e.g. for Visegrad countries. The Slovak Republic is the only economy from V4 that does not have their currency, and it is a member of the euro area.

\section{References}

Antonakakis, N. \& Vergos, K. (2013). Sovereign bond yield spillovers in the Euro zone during the financial and debt crisis. Journal of International Financial Markets, Institutions and Money, 26(1). http://dx.doi.org/10.1016/jint fin.2013.06.004.

Břešt’an, R. (2011). Noční můra z Portugalska. Ekonom, 55(13).

Chionis, D., Pragidis, I., \& Schizas, P. (2014). Long-term government bond yields and macroeconomic fundamentals: Evidence for Greece during the crisis-era. Finance Research Letters, 11(3). http://dx.doi.org/10.1016/j.frl.2014.02.003. 
Claeys, P., \& Vašíček, B. (2014). Measuring Bilateral Spillover and Testing Contagion on Sovereign Bond Markets in Europe. Journal of Banking and Finance, 46(C). 1 http://dx.doi.org/0.1016/j.jbankfin.2014.05.011.

Costantini, M., Fragetta, M., \& Melina, G. (2014). Determinants of sovereign bond yield spreads in the EMU: An optimal currency area perspective. European Economic Review, 70(1). http://dx.doi.org/10.1016/j.euroecorev.2014.06.004.

Dolejš, R. (2010). Na flamenco času dost. Ekonom, 54(10).

Drachal, K. (2016). Analysis of a time-varying risk premium in the Visegrad group. MEST Journal, 4(1).

Drachal, K. (2015). The Structural Stability of a One-Day Risk Premium in View of the Recent Financial Crisis. Expert Journal of Economics, 3(2).

Ejsing, J., Grothe, M., \& Grothe. O. (2015). Liquidity and credit premia in the yields of highly-rated sovereign bonds. Journal of Empirical Finance, 33(1). http://dx.doi.org/10.1016/j.jempfin.2015.04.001.

Engle, R. F., Focardi, S. M., \& Fabozzi, F. J. (2007). ARCH/GARCH Models in Applied Financial Econometrics. In: Encyclopedia of Financial Models. Retrieved from http://onlinelibrary.wiley.com/doi/10.1002/9781118182635.ef $\mathrm{m} 0062 /(13.12 .2015)$.

Galariotis, E. C., Krokida, S. I., \& Spyrou. S. I. (2015). Bond market investor herding: Evidence from the European financial crisis. International Review of $\mathrm{Fi}$ nancial Analysis, January, http://dx.doi.org/10.1016/j.irfa.2015.01.001.

Guarín, A., Moreno J. F. \& Vargas. H. (2014). An Empirical Analysis of the Relationship between US and Colombian Long-Term Sovereign Bond Yields. Ensayos sobre Política Económica, 32(74). http://dx.doi.org/10.1016/S01204483(14)70028-4.

Hruška, B. (2010). Zorba se zlobí. Ekonom, 54(7).

Němec, J. (2010). Z keltského tygra prasetem. Ekonom, 54(46).

Němec, J. (2011a). Od drachmy k euru a zpět. Ekonom, 55(20).

Němec, J. (2011b). Bankrot už není tabu. Ekonom, 55(38).

Němec, J. (2012). Účet na záchranu ,prasátek“"? Kvůli Itálii až bilion eur. Ekonom, $56(25)$.

Stavárek, D. (2010). Exchange rate volatility and the asymmetric fluctuation band on the way to the Eurozone. Applied Economics Letters, 17(1). http://dx.doi.org/10.1080/13504850701719827.

Zhou, Y. (2014). Modeling the joint dynamics of risk-neutral stock index and bond yield volatilities. Journal of Banking \& Finance, 38(1). http://dx.doi.org/10.1016/j.jbankfin.2013.10.010. 


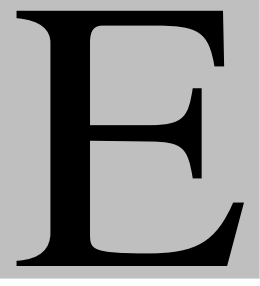

Q U I L I B R I U M

Quarterly Journal of Economics and Economic Policy

\section{Determinants of Growth in European Union Countries}


